\title{
Slope instability along some sectors of the road to La Bufadora
}

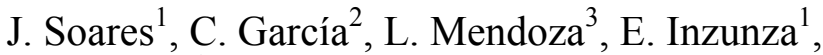 \\ F. Jáuregui ${ }^{4} \&$ J. Obregón ${ }^{5}$ \\ ${ }^{1}$ Engineering Faculty of the Universidad Autónoma de Baja California \\ UABC in Ensenada, Baja California, Mexico \\ ${ }^{2}$ Instituto Municipal de Investigación y Planeación, Mexico \\ ${ }^{3}$ Centro de Inv. Cientifica y de Ed. Superior de Ensenada CICESE, \\ Mexico \\ ${ }^{4}$ Social and Administrative Sciences Faculty of UABC, Mexico \\ ${ }^{5}$ Subheadship of the Civil Protection County Agency, Ensenada, \\ Baja California. Mexico
}

\begin{abstract}
La Bufadora is a famous water sprout and a tourist spot located about one hour drive south of the city of Ensenada, in the state of Baja California, Mexico. The route to La Bufadora is a narrow curvy road with unstable slopes. On a $4 \mathrm{~m}$. stretch, the road continuously subsides, probably due to a sector of the Agua Blanca Fault that crosses the Punta Banda Peninsula. Swarms of small earthquakes have been located in this same section by RESNOM since 1997 (CICESE, RESNOM Online catalog. http://sismologia.cicese.mx/resnom/ catalogo/datain.php) and unstable rocks presuppose a risk that is manifested in the occurrence of slips. In this paper we will show a slope classification made according to the need of attention as well as their remedial options. We document new evidence of an anthropogenic impact: a high pressure of tourist housing development in several places of the peninsula. We registered and identified the causes for the slope instability and landslides in the farthest point of the peninsula finding that they are due to the construction of an access road. The impacts registered and the measures taken by a net of wood stacks to measure slope deforestations by wind, rain and continuous car vibrations show an approximate 5\% loss in slope vegetation. This research allows the decision makers to implement a series of recommendations into the regulations they have regarding tourist areas to develop as well as access roads.

Keywords: slope instability, landslides, anthropogenic impact.
\end{abstract}




\section{Introduction}

The city of Ensenada in Baja California, Mexico is visited annually by approximately 350,000 tourists that either come aboard cruise ships or travel by car. One of its most important tourist attractions is "La Bufadora" ("The Blowhole") which is a famous spurt of sea water (Fig 1) located at the end of the Punta Banda Peninsula.

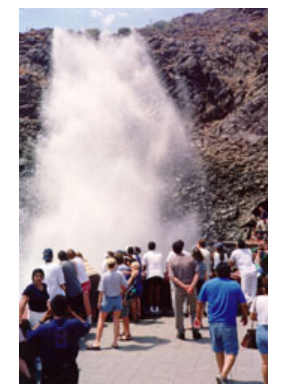

Figure 1: $\quad$ La Bufadora (The Blowhole) water spurt.

The road to La Bufadora starts approximately 27 kilometres south of the city of Ensenada towards the west, covering all the arm of the Punta Banda Peninsula facing the Todos Santos Bay.

Punta Banda is about 8 to $9 \mathrm{~km}$ in length and 2 to $6 \mathrm{~km}$ wide and it is filled with restaurants and small Mexican food stands as well as housing developments for retired Americans, tourists and locals. The road to Punta Banda diverges into several smaller tourists' sites mainly for activities such as fishing, scuba diving and kayaking.

About 5 kilometers before arriving to La Bufadora, there is an exit leading to a new asphalted road towards La Lobera, a major housing resort and golf course development planned for tourists.

\subsection{Tectonics}

Ensenada is located between the Pacific and North American plate boundary, on the San Andreas Fault zone (Soares and Acosta Chang [1]). One of the faults of this system, the Agua Blanca Fault, a major right-handed strike-slip fault is the main structural element affecting the Punta Banda Peninsula; it is divided in two segments limiting the northern and southern part of the Peninsula.

In 2000, González-Fernández et al. [2] proposed a complex geological model for Punta Banda after interpreting gravity and magnetic data using three dimensional inversion, suggesting the presence of three smaller ruptures along the Punta Banda Peninsula.

Figure 2 shows two of those ruptures located in the study area.

Scarce seismic activity in this region has been registered by the Centro de Investigación Científica y de Educación Superior de Ensenada (CICESE) since 1980, with small swarms of microseismicity occurring approximately every six 


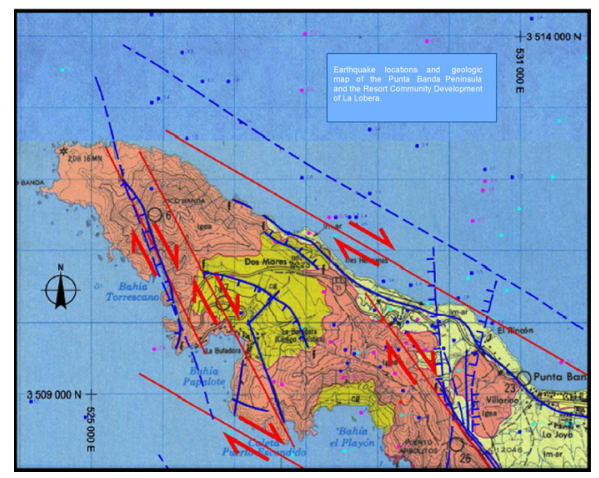

Figure 2: $\quad$ Proposed faults (dashed lines) and interpreted faults (solid lines) for the study area (modified from González-Fernández et al. [2]).

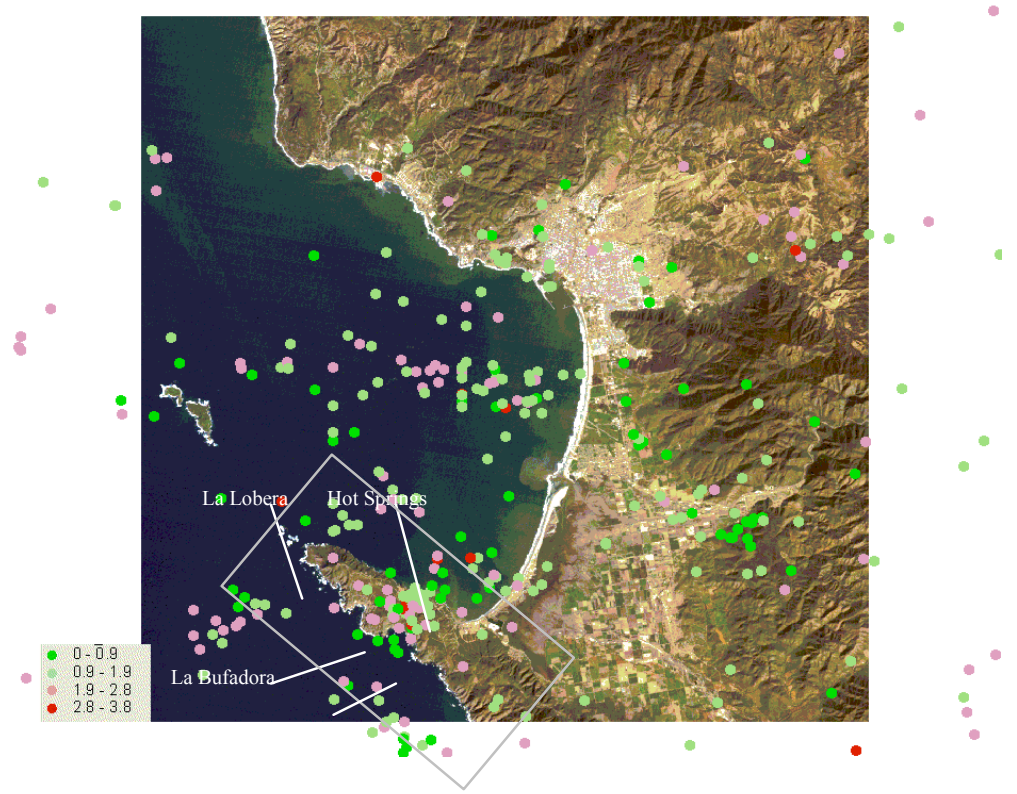

Figure 3: $\quad$ Microseismicity registered from 1982 to 2007 (CICESE [3]). The area in the rectangle comprises the Peninsula of Punta Banda.

months in one section of the main road to La Bufadora, near a hot spring area (Figure 3) and at El Playón Bay which shows evidence of normal faulting.

\section{Slope analysis}

Punta Banda has a maximum height of approximately 360 meters, sloping gradually to the bay in its north side and having extremely steep cliffs on its south side. Field Surveys were made in August of 2007 to contrast topographic 
maps, gather information of possible rupture zones and to deploy 35 stack poles on La Lobera Resort Development and on its access road to measure possible displacements. Preliminary information from the stacks was collected in January and February of 2008 (figure 4) and is still being collected.

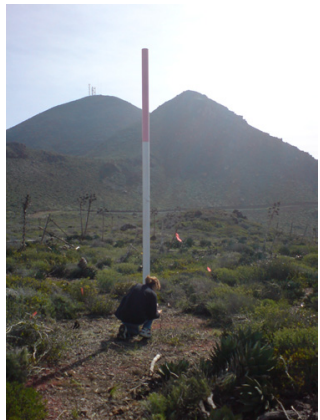

(a)

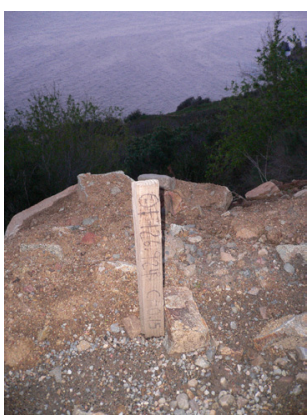

(b)

Figure 4: $\quad$ Stack pole deployment along the La Lobera Development (a) and on the access road to La Lobera Development (b).

A reconnaissance flight was made on February 2008 to have a panoramic view of the study area searching for evidence of fault traces or recent landslides. Aerial photographs were taken along the predetermined course to cover the main areas of interest. In order to track the aircraft position, a GPS unit was used synchronized with the camera to provide an accurate location for each photograph.

\subsection{Mudslides and landslides}

For three consecutive years, high temperature Santa Ana Winds that arise when high pressure builds over the high plateau regions of Nevada and Utah in the United States of America, blowing towards the Pacific Ocean, produced wildfires in the study area destroying the natural vegetation, with the hillsides remaining vulnerable to weathering and sliding, causing a high risk to the families living in the Punta Banda Peninsula mainly on the Esteban Cantú communal land. Santa Ana winds may blow at approximately at $65 \mathrm{~km} / \mathrm{h}$ with gusts of $110 \mathrm{~km} / \mathrm{h}$ with temperatures that can rise over $37^{0} \mathrm{C}$.

During the winter of 2007, runoff water from the storms reached high velocities due to the steep and burned bare slopes lacking the vegetation to hold the soil in place, resulting in flooding and mudslides in the lower areas (Figure 5)

Evidence of anthropogenic impact was found where the addition of loads due to the presence of a tourist housing development on the edges of the hillsides were built in areas where loess and sand forming hills are present (Figure 6), causing additional sliding. In this sector, $4 \mathrm{~m}$. of the road to La Bufadora have sunk approximately $5 \mathrm{~cm}$ in two years and earthquake swarms have been registered (CICESE [3]). 


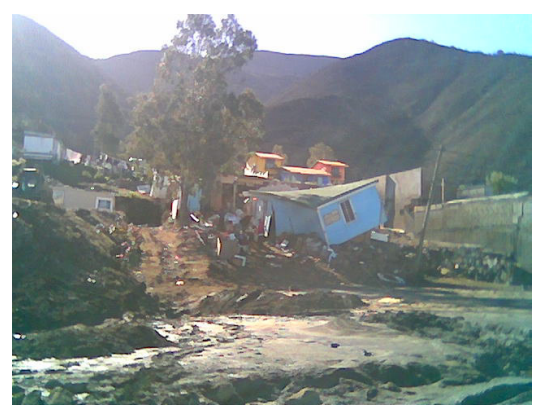

Figure 5: $\quad$ Flooding at the Esteban Cantú communal land in Punta Banda.

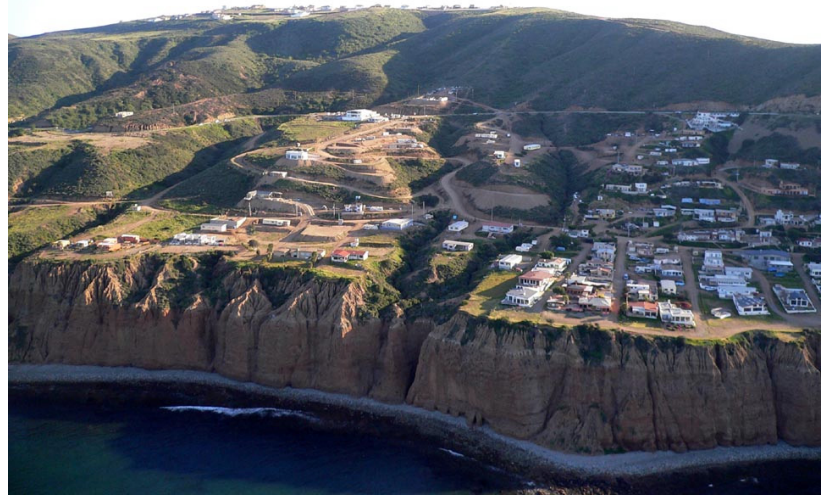

Figure 6: Tourist Housing near the area of El Rincón de las Ballenas where normal faulting and erosion due to rain precipitation are present, adding a risk to the residents.

\subsection{Roads}

In general, the road to La Bufadora subsides on several sectors aligned with the runoff water marks on the hills, even where preventive measures were taken inserting drainpipes in different locations. At the farthest point of the Punta Banda Peninsula, in 2004, an access asphalt road was built for La Lobera Development, where we found that the loads from the construction traffic when acting on the asphalt, generated the immediate responses shown in figure 7 as cracks and sinking and sliding of the road.

A rapid visual screening of the runoff water drainage ways indicates it ends immediately at the side of the road (Figure 7c), which will result in local erosion and could lead to waterlogged roads by mud blocking the pipe when exceptional 
rainfall delivers great volumes of water. Two of the pipes found were already blocked. It was also found that the cracking of the road is due to the lack of a good soil compaction and the sliding is the result of the removal of the natural vegetation cover by dropping debris material onto the side cross section (Figure 8) destabilizing the hill.

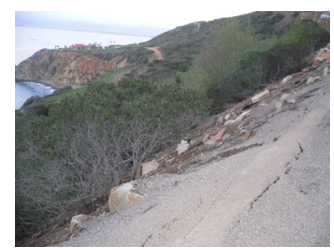

(a)

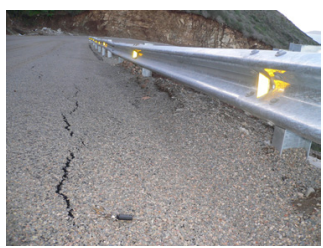

(b)

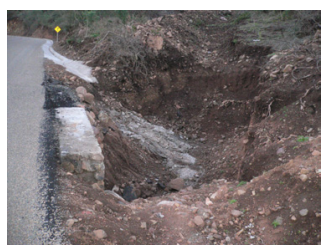

(c)

Figure 7: $\quad$ Sliding (a), cracking (b) and sinking (c) of the asphalt road to La Lobera.

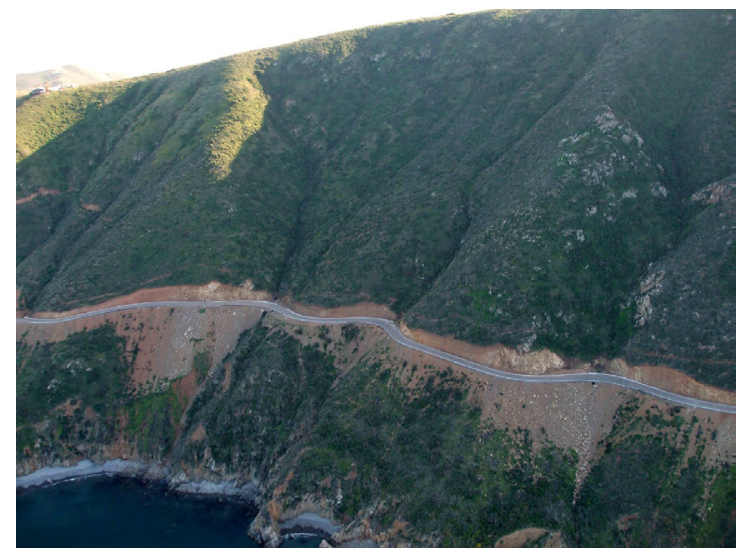

Figure 8: Aerial photograph showing debris material dropped to the hillside.

\subsection{The model}

Based on field recognition and maps, we have classified the slopes as shown in Figure 9 and their analysis is given in Table I.

In addition, it is strongly recommended as a preventive measure to avoid any building or development at least at a minimum distance of $50 \mathrm{~m}$. to the superficial trace of any fault.

The asphalt road to La Lobera does not fulfill its primary function, causing lack of safety for the users, as well as damage to their vehicles. In time, this could lead to a major rupture or sliding of the pavement if heavy machinery for the tourist development is transiting, leaving the community without any access to the main road. 


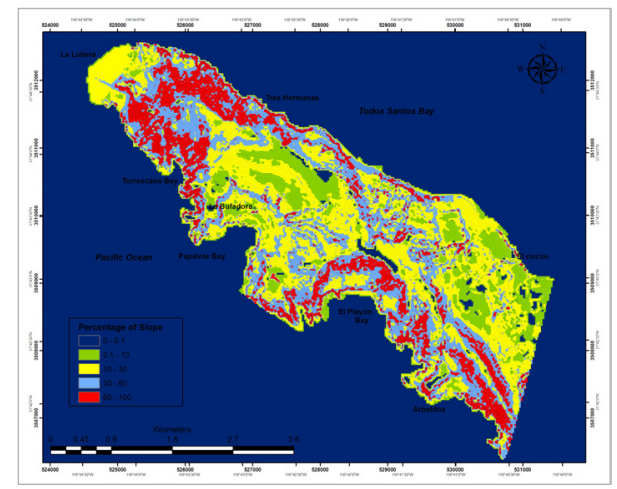

Figure 9: $\quad$ Slope classification in the Punta Banda Peninsula.

Table 1: $\quad$ Slope analysis.

\begin{tabular}{|c|c|l|}
\hline Slope Range (\%) & Slope Classification & Land Use Suitability \\
\hline $0-0.1$ & Flat & $\begin{array}{l}\text { Suitable for housing. Located } \\
\text { on the higher areas. No sliding } \\
\text { hazard. }\end{array}$ \\
\hline $0.1-10$ & Gradual & $\begin{array}{l}\text { If located on the higher areas, } \\
\text { planning for urban } \\
\text { development may be suitable. } \\
\text { The lower areas with these } \\
\text { slopes are located where loess } \\
\text { and sand form the soil and are } \\
\text { not recommended for urban } \\
\text { development They are } \\
\text { recommended for green areas. }\end{array}$ \\
\hline $10-30$ & $\begin{array}{l}\text { Housing development on } \\
\text { these slopes could be suitable } \\
\text { but costly. They will increase } \\
\text { the surface runoff. Not } \\
\text { recommended for } \\
\text { development where loess and } \\
\text { sand forming hills are present. }\end{array}$ \\
\hline $30-60$ & Moderate & Not recommended for housing \\
\hline $60-100$ & Not recommended for housing \\
\hline & &
\end{tabular}

In a natural way, the slopes in Punta Banda have been stabilized by native species of vegetation that are resistant to the prolonged droughts and require less water, capturing it mainly from the breeze. The destabilization of the hillsides caused by the removal of the vegetation in the construction of the access road to La Lobera represents a potential hazard specially in the rainy season where water will drain from the upper hill in large quantities and will have more energy, bringing down weathered material as avalanches of mud and the cracking of the road. 


\section{Proposed interventions and conclusions}

The construction of an energy dissipation device on pipes could repair the problem caused by the inadequate drainage system already built; however a constant, preventive and permanent maintenance of the road must be considered due to the inappropriate ground compaction and to the possibility of mudslides from the hills.

To achieve the development of the infrastructure activities on La Lobera it is important to consider the immediate reforestation of the landscape and to protect the remaining one, as a mean to solve problem areas which have been already modified, to protect the hillsides and avoid natural hazards mainly in the rainy season.

It is also important as a safety measure to consider the construction of an alternate route to use in case of an eventuality (v. gr. earthquakes, wildfires) as well as a contingency plan for wildfires and in case it occurs, to promote the fast reforestation for the slope stabilization.

It is highly recommended to build a protected area and a breakwater at $\mathrm{La}$ Lobera to secure boats to use in case of any emergencies or illness of the residents.

Slope instability in the study region is mostly due to the pressures caused by the housing developments for tourists. Construction builders should build in areas not susceptible to landslides as recommended in this paper, to ensure the future of the tourism as one of the main variables in the economic growth for Ensenada.

\section{References}

[1] Soares J. and J. Acosta Chang. An application of the seismic microzonation to the critical facilities in the city of Ensenada, Baja California, Mexico. Earthquake Resistant Engineering Structures V. WIT Press pp. 63-72. 2005.

[2] A. González-Fernández, B. Martín-Atienza y S. Paz-López. Identificación de fallamiento en la Península de Punta Banda, B. C. a partir de datos de topografía, magnetometría y gravimetría. GEOS. Vol. 20 No 2, pp 98-106. 2000.

[3] Centro de Investigación Científica y de Educación Superior de Ensenada (CICESE). RESNOM Online catalog. http://sismologia.cicese.mx/resnom/ catalogo/datain.php 